\section{Occurrence of white gelatinous foam on the beaches of Kollam (southwest coast of India) due to the senescent bloom of Phaeocystis globosa}

\author{
N. V. Madhu*, P. Anil, C. R. Vishal, \\ K. R. Muraleedharan, A. Parvathi, \\ T. Gireesh Kumar, K. S. Arya and S. Hafza \\ CSIR-National Institute of Oceanography, Regional Centre, \\ Kochi 682 018, India
}

An unusual white gelatinous foam ( 2 ft high) was detected on the beaches of Kollam (Mundakkal), Kerala, southwest coast of India. It extended to $\sim 300 \mathrm{~m}$ alongshore on 10 June 2019 from 7 am and sustained till around $10 \mathrm{am}$. CSIR-National Institute of Oceanography, Regional Centre, Kochi conducted a field survey and water sampling in the foam-affected coastal region on 11 June 2019 to identify the scientific cause behind this unusual foam formation. Analytical results of the study showed enhanced inorganic nutrients and dissolved forms of organic matter, carbon and nitrogen. The proliferation of a marine prymnesiophyte, Phaeocystis globosa Scherffel $(>320 \times$

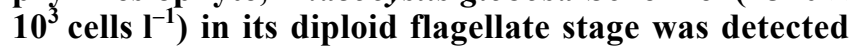
in the samples along with a higher abundance of prokaryotes $\left(>1.2 \times 10^{6}\right.$ VLPs $\left.\mathrm{ml}^{-1}\right)$ and viruses $(>4 \times$ $\left.10^{7} \mathrm{VLPs} \mathrm{ml}^{-1}\right)$. The study revealed that this foam event in Kollam beach area was merely the biogeochemical manifestation of the senescent bloom of $P$. globosa. Furthermore, since the foam formation due to blooming of $P$. globosa is the rarest coastal event in tropical marine waters, the study in the Indian waters (Kollam beach) is highly significant considering its potential impact on the marine ecosystems.

Keywords: Algal bloom, coastal water, gelatinous foam, phytoplankton, Phaeocystis globosa.

THE coastal marine waters are highly prone to the occurrence of various disastrous algal blooms (called as harmful algal blooms or HABs) of diverse phytoplankton functional groups (PFGs). Among these, diatoms and dinoflagellates are the most susceptible blooms causing PFGs in the tropical/subtropical waters ${ }^{1}$. However, frequency in the occurrence of HABs of high-latitude species has been increasing in the tropical/subtropical coastal waters as a result of potential impacts of anthropogenic climate change ${ }^{2}$. The frequent blooming of such alien species alters the prevailing food-web structures and ecosystem functions of these coastal areas ${ }^{3,4}$. Recently (10 June 2019), the occurrence of an unusual white gelatinous foam of $\sim 2 \mathrm{ft}$ height (extended $\sim 300 \mathrm{~m}$ alongshore) was reported on the beaches of Kollam (Mundakkal), Kerala,

*For correspondence. (e-mail: nmadhu@nio.org)
India ${ }^{5}$. It appeared early morning at 7 am and persisted till $10 \mathrm{am}$. Later, it got dissipated from the beach due to heavy rainfall. The local residents intimated that there were no health issues due to this foam event.

A scientific team from CSIR-National Institute of Oceanography (NIO), Regional Centre, Kochi visited the coastal region on 11 June 2019 and carried out sampling and measurements from two locations ( $\mathrm{S} 1-8^{\circ} 52^{\prime} 08.55^{\prime \prime} \mathrm{N}$ and $\left.\mathrm{S} 2-76^{\circ} 35^{\prime} 52.59^{\prime \prime} \mathrm{E}\right)$, where the foam was seen (Figure 1). At the time of water sampling, the shore experienced high winds $\left(>9 \mathrm{~ms}^{-1}\right)$ and waves $(\sim 2 \mathrm{~m})$, and witnessed the formation of white foam from the waves. Nevertheless, this white foam was not as thick as the gelatinous foam seen on the previous day (Figure 2). Moreover, faint yellowish foam-like patches were also detected in the inshore waters off the shore. Temperature, salinity, $\mathrm{pH}$, dissolved oxygen (DO), inorganic nutrients ${ }^{6}$, dissolved forms of organic matter (DOM), carbon (DOC) and nitrogen $(\mathrm{DON})^{7}$, phytoplankton pigments ${ }^{8}$ and species abundance and composition ${ }^{9}$, bacterial and viral abundances were determined using oceanographic techniques and protocols ${ }^{10}$. For the scanning electron microscope (SEM)-based photomicrographs, the phytoplankton sample was initially rinsed with distilled water and then dehydrated with a graded ethanol series. Subsequently,

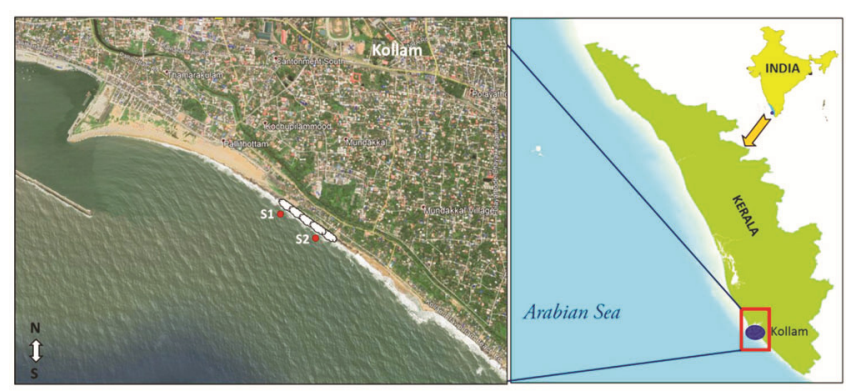

Figure 1. Study area (Kollam (Mundakkal), Keralal, India, foamaffected region is marked by white bubbles) and sampling locations (red circles $-\mathrm{S} 1$ and $\mathrm{S} 2$ ).

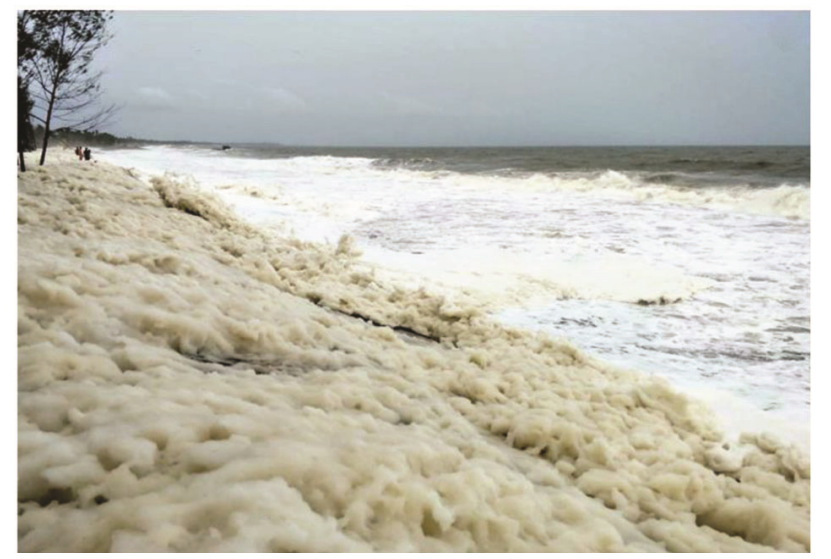

Figure 2. White gelatinous foam layers on the beaches of Kollam on 10 June 2019. 
the dried cell specimens were mounted on a stub and examined using a SEM (model no. TESCAN VEGA3 $\mathrm{SBH})$ for image processing. The wind speed $(\mathrm{m} / \mathrm{s})$ and wave height $(\mathrm{m})$ data were retrieved from the European Centre for Medium-Range Weather Forecasts (ECMWF) (https://apps.ecmwf.int/datasets/data/interimfull-daily), and sea surface temperature (SST) was taken from NOAA Coast Watch-Ocean Watch (https://cwcgom. aoml.noaa.gov).

The satellite-derived data (daily mean) showed relatively higher wind speed $\left(9.23 \mathrm{~m} \mathrm{~s}^{-1}\right)$ and waves $(>3 \mathrm{~m})$ all along the coast of Kollam on 10 June 2019, together with a marked decrease in SST $\left(<29.5^{\circ} \mathrm{C}\right)$ compared to the previous day (Figure 3). The salinity (34.3), $\mathrm{pH}(<8)$ and DO $(<4.5 \mathrm{ml} / \mathrm{l})$ of the water samples collected on 11 June 2019 showed typical hydro-chemical feature of tropical near-shore waters (Table 1). However, the inorganic nutrients such as ammonium $(5.75$ and $1.64 \mu \mathrm{M})$, nitrite $(0.7$ and $0.7 \mu \mathrm{M})$, nitrate $(4.83$ and $4.17 \mu \mathrm{M})$, phosphate $(1.42$ and $1.7 \mu \mathrm{M})$ and silicate $(63.16$ and $21.25 \mu \mathrm{M})$ were strikingly higher at sampling locations S1 and S2 respectively. Likewise, enhanced levels of DOM (338.85 and $361.04 \mu \mathrm{M})$, DOC (188.25 and $200.58 \mu \mathrm{M})$ and DON $(59.2$ and $66.91 \mu \mathrm{M})$ were detected in the water samples at sampling locations $\mathrm{S} 1$ and $\mathrm{S} 2$ respectively.

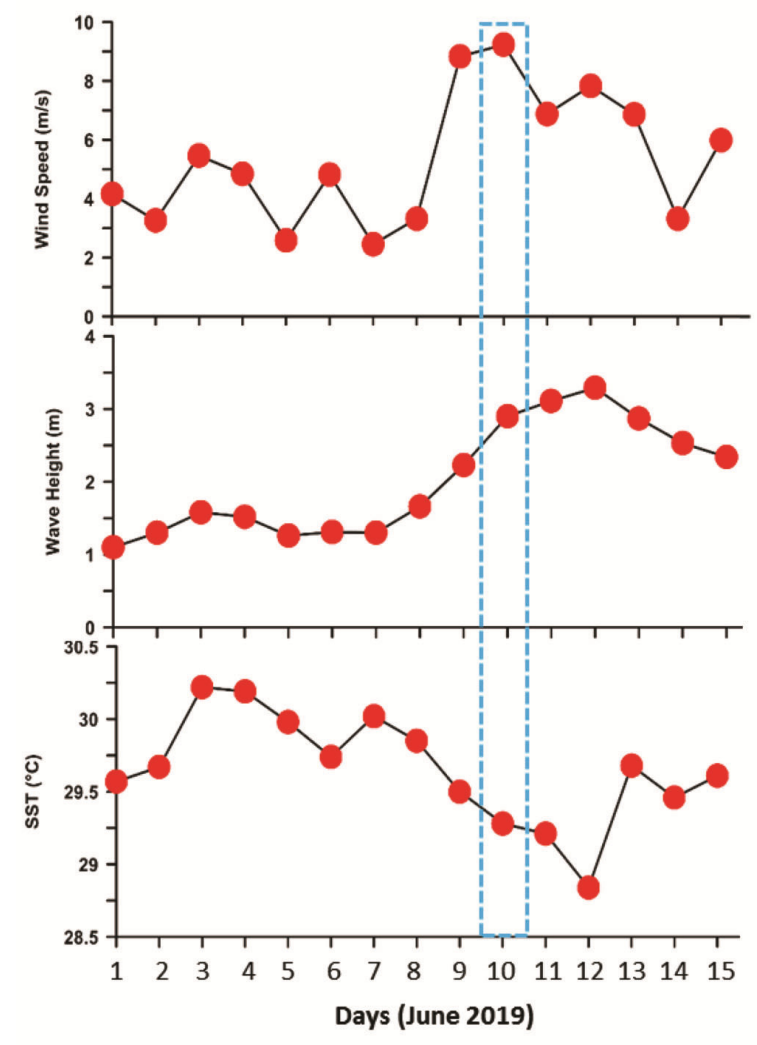

Figure 3. Mean (daily) wind speed $\left(\mathrm{ms}^{-1}\right)$, wave height (m) (https://apps.ecmwf.int/datasets/data/interim-full-daily) and sea surface temperature (SST; $\left.{ }^{\circ} \mathrm{C}\right)$ (https://apps.ecmwf.int/datasets/data/interimfull-daily) in the coastal waters of Kollam during June 2019.
The prokaryotic abundance was relatively low (S1 -

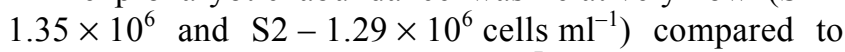
viral abundance $\left(\mathrm{S} 1-4.68 \times 10^{7}\right.$ and $\mathrm{S} 2-4.01 \times$ $10^{7}$ VLPs $\mathrm{ml}^{-1}$ ). Chlorophyll $a$, the proxy of phytoplankton biomass, was noticeably higher at $\mathrm{S} 1\left(10.21 \mathrm{mg} \mathrm{m}^{-3}\right)$ and S2 $\left(7.23 \mathrm{mg} \mathrm{m}^{-3}\right)$. The phytoplankton marker pigments showed a distinct dominance of fucoxanthin (S1 2.29 and $\mathrm{S} 2-1.89 \mathrm{mg} \mathrm{m}^{-3}$ ) over other pigments such as zeaxanthin, chlorophyll $c 2$, beta carotene, etc. (Table 1). The phytoplankton abundance was substantially higher at S1 $\left(607.16 \times 10^{3}\right.$ cells/l) and S2 $\left(349 \times 10^{3}\right.$ cells $\left./ 1\right)$. The light microscopic (LM, inverted binocular, Leica DMi8) analysis of phytoplankton samples showed an aggregation (40-50 $\mu \mathrm{m}$ long) of randomly distributed oblong (slightly)-shaped structures, comprising 20-50 solitary cells (Figure $4 a$ ). The length and breadth of each of these cells was $\sim 5-6$ and $2-3 \mu \mathrm{m}$ respectively. The SEM

Table 1. Major chemical and biological parameters from the nearshore waters of Kollam (Mundakkal), Kerala, India, on 11 June 2019

\begin{tabular}{|c|c|c|}
\hline \multirow[b]{2}{*}{ Parameters } & \multicolumn{2}{|c|}{ Sampling location } \\
\hline & $\mathrm{S} 1$ & $\mathrm{~S} 2$ \\
\hline \multicolumn{3}{|l|}{ Chemical } \\
\hline Salinity & 34.3 & 34.3 \\
\hline $\mathrm{pH}$ & 7.38 & 7.91 \\
\hline Dissolved oxygen (ml/1) & 4.43 & 4.2 \\
\hline Ammonia $(\mu \mathrm{M})$ & 5.75 & 1.64 \\
\hline Nitrite $(\mu \mathrm{M})$ & 0.07 & 0.07 \\
\hline Nitrate $(\mu \mathrm{M})$ & 4.83 & 4.17 \\
\hline Phosphate $(\mu \mathrm{M})$ & 1.42 & 1.7 \\
\hline Silicate $(\mu \mathrm{M})$ & 63.16 & 21.25 \\
\hline Dissolved organic matter $(\mu \mathrm{M})$ & 338.85 & 361.04 \\
\hline Dissolved organic carbon $(\mu \mathrm{M})$ & 188.25 & 200.58 \\
\hline Dissolved organic nitrogen $(\mu \mathrm{M})$ & 59.26 & 66.91 \\
\hline \multicolumn{3}{|l|}{ Biological } \\
\hline Chlorophyll $a\left(\mathrm{mg} \mathrm{m}^{-3}\right)$ & 10.21 & 7.23 \\
\hline Chlorophyll c3 $\left(\mathrm{mg} \mathrm{m}^{-3}\right)$ & 0.67 & 0.61 \\
\hline Chlorophyll c2 $\left(\mathrm{mg} \mathrm{m}^{-3}\right)$ & 0.37 & 0.22 \\
\hline B-Carotene $\left(\mathrm{mg} \mathrm{m}^{-3}\right)$ & 0.45 & 0.23 \\
\hline Fucoxanthin $\left(\mathrm{mg} \mathrm{m}^{-3}\right)$ & 2.29 & 1.89 \\
\hline Diadinoxanthin $\left(\mathrm{mg} \mathrm{m}^{-3}\right)$ & 0.19 & 0.15 \\
\hline $19^{\prime}$ Butanoyloxyfucoxanthin $\left(\mathrm{mg} \mathrm{m}^{-3}\right)$ & 0.09 & 0.05 \\
\hline $19^{\prime}$ Hexanoyloxyfucoxanthin $\left(\mathrm{mg} \mathrm{m}^{-3}\right)$ & 0.03 & 0.02 \\
\hline Zeaxanthin $\left(\mathrm{mg} \mathrm{m}^{-3}\right)$ & 0.94 & 0.34 \\
\hline $\begin{array}{l}\text { Phytoplankton abundance } \\
\quad\left(\text { no. } \times 10^{3} \text { cells } 1^{-1}\right)\end{array}$ & 607.16 & 349 \\
\hline Rhizosolenia sp. & - & 2.5 \\
\hline Ceratulina pelagica & 5 & - \\
\hline Guinardia striata & 5 & - \\
\hline Surirella fastuosa & 5 & - \\
\hline Navicula sp. & 0.01 & 5 \\
\hline Entomoneis sp. & 0.03 & 2.5 \\
\hline Pleurosigma sp. & 0.16 & 5 \\
\hline Nitzschia sp. & 5 & - \\
\hline Pseudonitzschia sp. & 15 & 5 \\
\hline Cylindrotheca closterium & 5 & 5 \\
\hline Phaeocystis globosa* & 527 & 324 \\
\hline Viral abundance $\left(\right.$ no. $\times 10^{7}$ VLPs $\mathrm{ml}^{-1}$ ) & 4.68 & 4.01 \\
\hline Prokaryotes $\left(\right.$ no. $\times 10^{6}$ VLPs $\left.\mathrm{ml}^{-1}\right)$ & 1.35 & 1.29 \\
\hline
\end{tabular}

*Bloom species. 

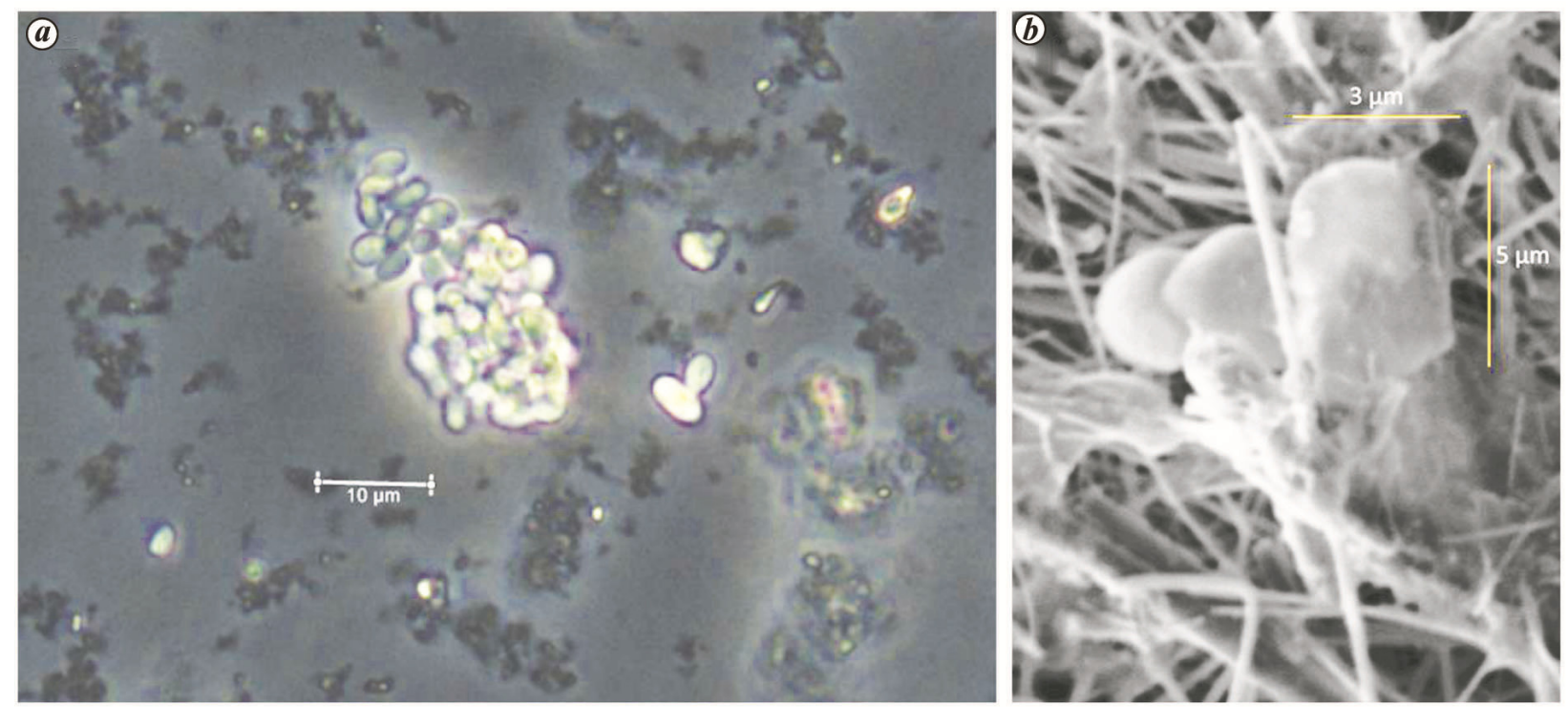

Figure 4. $\boldsymbol{a}$, Light microscopic photomicrograph of aggregations of Phaeocystis globosa-diploid flagellate cell type. $\boldsymbol{b}$, Scanning electron microscope photomicrograph of diploid flagellate type.
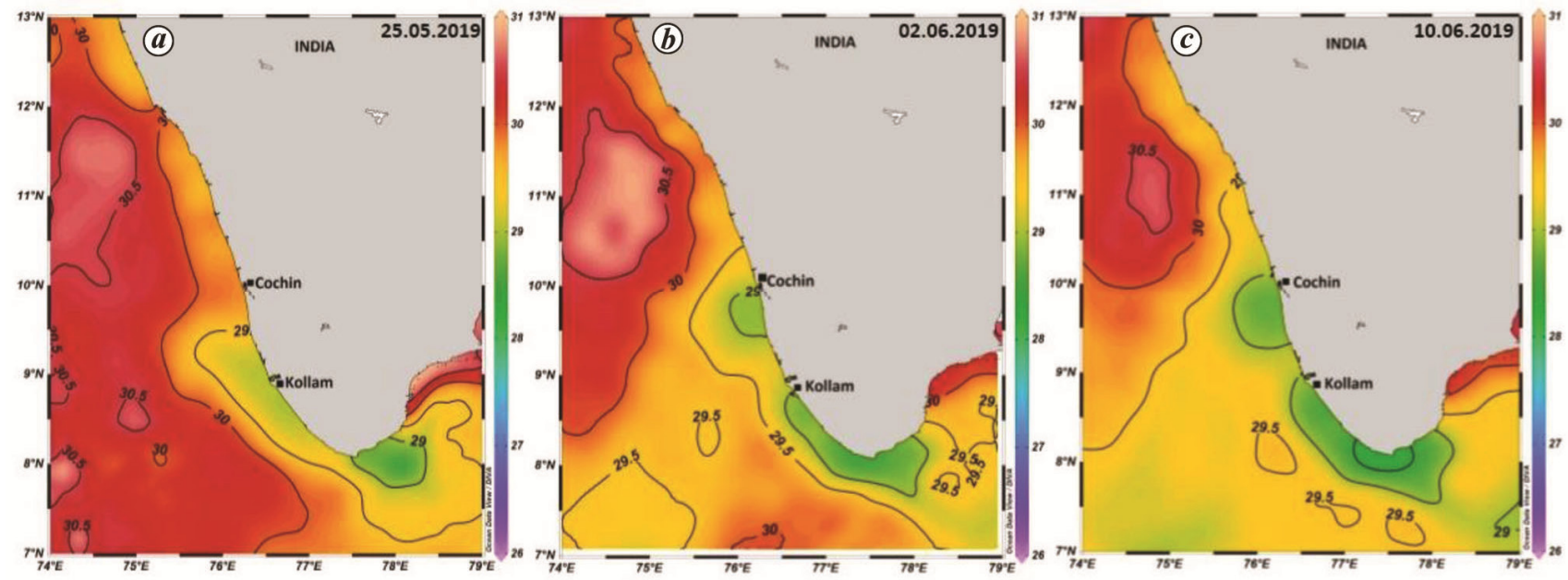

Figure 5. Distribution of mean (daily) sea surface temperature (SST; ${ }^{\circ} \mathrm{C}$ ) in the eastern Arabian Sea during the onset of the southwest monsoon (May/June 2019; https://cwcgom.aoml.noaa.gov).

photomicrograph of the solitary cell was much clearer than the LM image for characterizing the morphological features (Figure $4 b$ ). The cells were more or less oblong in shape and also a hazy grove-like impression was visible in the middle of the cells (Figure $4 \mathrm{~b}$ ). The morphological features of this cellular entity showed similarities with the original description of the marine prymnesiophyte, Phaeocystis globosa Scherffel described by Scherffel $^{11}$, Kornmann ${ }^{12}$ and Rousseau et al. ${ }^{13}$. There are four distinct cell types in the life cycle of P. globosa, i.e. two types of haploid flagellates $(3-6 \mu \mathrm{m}$, seen before colony formation), a diploid colonial cell (4-8 $\mu \mathrm{m}$, embedded in the mucilaginous colony) and a large diploid flagellate (4-9 $\mu \mathrm{m}$, seen after colony disruption) ${ }^{13}$. Since the $P$. globosa cells were detected from the near-shore waters of Kollam during the decaying phase of the bloom (i.e. after disruption of the colony), the cell type could be of a diploid flagellate ${ }^{13}$. However, the two flagellae and the haptonema, the characteristic cellular structure of the diploid cell type of $P$. globosa, could not been distinguished properly in the SEM image because of the lack of clarity (Figure $4 b$ ). Although while considering the morphological features of the bloom species as well as the physical characteristics of the foam, it could be categorically assumed that the cellular aggregation encountered in the foam-affected near-shore waters of Kollam was the diploid flagellate cell type of $P$. globosa Scherffel $^{13}$. The total phytoplankton abundance comprised of the exclusive aggregations $(>80 \%)$ of these nanoplanktonic diploid flagellates of $P$. globosa (Table 1). 
Although the genus Phaeocystis has a worldwide distribution as diverse species, their blooming is mostly restricted in high-latitude seas ${ }^{13,14}$. Occurrences of Phaeocystis blooms have been reported from tropical waters as well ${ }^{4,14}$. Usually, Phaeocystis species lead a polymorphic life, alternating between free-living solitary vegetative cells $(\sim 3-9 \mu \mathrm{m})$ and spherical (mostly), giant gelatinous colonies (up to $5 \mathrm{~mm}$ diameter) comprised of $>10,000$ cells $^{14}$. The balloon-like colonies produce significant amounts of DOM, rich in glucan and mucopolysaccharides, in which the cells are randomly distributed ${ }^{14}$. During the waning phase of the bloom, Phaeocystis colonies undergo disruption and release mucus, which ultimately enhances the mucilaginous condition of the bloom-affected waters which would eventually cause foam formation ${ }^{15}$. In fact, these white gelatinous foams usually lead to shellfish mortality, production of dimethyl sulphide, and at times are a nuisance to shore-based fishing activities ${ }^{14,16}$. Nutrient stress, especially $\mathrm{PO}_{4}$ or $\mathrm{NO}_{3}$ limitation, is considered as one of the major causes of the collapse of $P$. globosa colonies $^{16}$. As far as the marker pigments are concerned, Phaeocystis blooms (particularly $P$. pouchetii and $P$. antartica) contain two derivatives of fucoxanthin, i.e. 19' hexanoyloxyfucoxanthin and 19' butanoyloxyfucoxanthin ${ }^{17}$. However, the natural $P$. globosa blooms do not contain these two marker pigments in higher levels; instead, they contain moderate amounts of chlorophyll $c 3$ and fucoxanthin ${ }^{17}$. The detection of the relative dominance of fucoxanthin and chlorophyll $c 3$ over other marker pigments from S1 and S2 indicates the natural occurrence of $P$. globosa bloom (Table 1).

Like prokaryotes, viruses have also been recognized as one of the significant members of the marine microbial food web ${ }^{18}$. They infect not only the prokaryotes in the marine ecosystems, but the whole phytoplankton community as well ${ }^{18}$. In Phaeocystis cells, viral infection normally induces nutrient remineralization, stimulating bacterial activity and subsequently forces the food web towards a more regenerative system via the microbial loop $^{3,18}$. The viral lysis of Phaeocystis thus enhances release of climatically active organic sulphur compounds (dimethyl sulphoniopropionate), the precursor of dimethyl sulphide ${ }^{16}$. The significant increase of viral count $\left(>4 \times 10^{7} \mathrm{VLPs} \mathrm{ml}^{-1}\right)$ observed at S1 and S2, compared to a previous study ${ }^{19}$, indicates that there could be putative viruses specific to $P$. globosa, and this may be one of the reasons for the termination of $P$. globosa bloom in the coastal waters of Kollam ${ }^{18}$.

The present study revealed that the foam event reported from Mundakkal beach, Kollam on 10 June 2019 was due to the post-bloom biogeochemical manifestations of $P$. globosa ${ }^{5}$. The senescent bloom of P. globosa observed in the near-shore waters of Kollam may have profusely proliferated a few days before the reported foam event ${ }^{5}$. Later on, gelatinous foams might have evolved from the decayed bloom waters due to prevailing wind action and subsequently might have been transported to the beach area. In fact, reports of $P$. globosa blooms in low-latitude seas are limited and mostly restricted to low-latitude upwelling regimes ${ }^{4}$. As far as Indian waters are concerned, $P$. globosa blooms have not been reported elsewhere, except in the open waters of the Arabian $\mathrm{Sea}^{20}$. Although the southwest coast of India is recognized as one of the major upwelling zones in the eastern Arabian Sea, the proliferation of P. globosa in connection with the upwelling process has not been reported. The physical signs of upwelling, in general, on the southwest coast of India could be observed since the second half of May 2019 (ref. 21). However, its chemical and biological indications were visible only after June 2019 (ref. 21). Indeed, the present foam event occurred during the onset of the southwest monsoon (beginning of June). The satellite SST-derived data showed a gradual surface water cooling $\left(<29.5^{\circ} \mathrm{C}\right)$ in this region since May end (Figure 5). However, this marginal cooling was not enough to substantiate the occurrence of coastal upwelling in the near-shore waters of Kollam during the foam event, since the sampling locations are very close to the beach. Even then, based on these verifications, we assume that a bloom of P. globosa might have developed in the coastal waters of Kollam due to nutrient enrichments enabled by either coastal upwelling or prevailing water column turbulence prior to the pre-monsoonal (May end to June beginning in 2019) wind stress and associated rainfall. Due to the socio-ecological menace created by the extensive $P$. globosa blooms, urgent measures should be taken up to mitigate the large-scale spreading of this HAB species in the Indian coastal waters.

1. Smayda, T. J., Harmful algal blooms: their ecophysiology and general relevance to phytoplankton blooms in the sea. Limnol. Oceanogr., 1997, 42, 1137-1153.

2. Hallegraeff, G. M., Ocean climate change, phytoplankton community responses, and harmful algal blooms: a formidable predictive challenge. J. Phycol., 2010, 46, 220-235.

3. Azam, F. et al., The ecological role of water-column microbes in the sea. Mar. Ecol. Prog. Ser., 1983. 10, 257-263.

4. Doan, N. H., Nguyen, N. L. and Dippner, J. W., Development of Phaeocystis globosa blooms in the upwelling waters of the SouthCentral coast of Viet Nam. J. Mar. Syst., 2010, 83, 253-261.

5. Mathrubhumi Daily, Kollam edition, 11 June 2019.

6. Grasshoff, K., Ehrhardt, M. and Kremling, K. (eds), Methods of Seawater Analysis, Verlag Chemie, Weinhein, Germany, 1983, 2nd edn.

7. Sharp, J. H. et al., Analyses of dissolved organic carbon in seawater: the JGOFS EqPac methods comparison. Mar. Chem., 1995, 48(2), 91-108.

8. Heukelem, V., HPLC phytoplankton pigments: sampling, laboratory methods, and quality assurance procedures. In Ocean Optics Protocols for Satellite Ocean Color Sensor, NASA Technical Memorandum, 2002, pp. 258-268.

9. Thomas, C. R. (ed.), Identifying Marine Phytoplankton, Academic Press, London, UK, 1997, pp. 634-635.

10. Patel, A. et al., Virus and prokaryote enumeration from planktonic aquatic environments by epifluorescence microscopy with SYBR Green I. Nature Protoc., 2007, 2, 269-276. 
11. Scherffel, A., Phaeocystis globosa. n. sp. (Vorläufige Mittheilung). Ber. Dtsch. Bot. Ges., 1899, 17, 317-318.

12. Kornmann, P., Beobachtungen an Phaeocystis-Kulturen. Helgol. Wiss. Meeresunters., 1955, 5, 218-233.

13. Rousseau, V. et al., Characterization of Phaeocystis globosa (Prymnesiophyceae), the blooming species in the southern North Sea. J. Sea Res., 2013, 76, 105-113.

14. Schoemann, V. et al., Phaeocystis blooms in the global ocean and their controlling mechanisms: a review. J. Sea Res., 2005, 53, 4366.

15. Lancelot, C., The mucilage phenomenon in the continental coastal waters of the North Sea. Sci. Total Environ., 1995, 165, 83-112.

16. Liss, P. S., Malin, G., Turner, S. M. and Holligan, P. M., Dimethyl sulphide and phaeocystis: a review. J. Mar. Syst., 1994, 5, 41-53.

17. Antajan, E., Chretiennot-Dinet, M. J., Leblanc, C., Daro, M. H. and Lancelot, C., 19'-Hexanoylfucoxanthin may not be the appropriate pigment to trace occurrence and fate of Phaeocystis: the case of P. globosa in Belgian coastal waters. J. Sea Res., 2004, 52, $165-177$.

18. Brussaard, C. P. D., Bratbak, G., Baudoux, A.-C. and Ruardij, P., Phaeocystis and its interaction with viruses. Biogeochemistry, 2007, 83, 201-215.
19. Parvathi, A. et al., High incidence of lysogeny in the oxygen minimum zones of the Arabian Sea (southwest coast of India). Viruses, 2018, 10, 588; doi:10.3390/v10110588.

20. Madhupratap, M., Sawant, S. and Gauns, M., A first report on a bloom of the marine prymnesiophycean, P. globosa, from the Arabian Sea. Oceanologica Acta, 2000, 23, 83-90.

21. Smitha, B. R., Sanjeevan, V. N., Vimalkumar, K. G. and Revichandran, C., On the upwelling off the southern tip and along the west coast of India. J. Coastal Res., 2008, 24(4C), 95-102.

ACKNOWLEDGEMENTS. We thank Dr P. K. Dinesh Kumar (CSIRNational Institute of Oceanography, Regional Centre, Kochi), for providing the necessary facilities and encouragement.

Received 29 December 2019; revised accepted 25 August 2020

doi: $10.18520 / \mathrm{cs} / \mathrm{v} 119 / \mathrm{i} 8 / 1371-1375$ 